\author{
P. Campisi, A. M. Mannino, G. Venturella \& S. Ravera
}

\title{
A first contribution to the cryptogamic flora of "Bosco Pomieri" (Northern Sicily)
}

\begin{abstract}
Campisi, P., Mannino, A. M., Venturella, G. \& Ravera, S.: A first contribution to the cryptogamic flora of "Bosco Pomieri" (Northern Sicily). — Borziana 1: 35-51. 2020.

This is the first contribution to the cryptogamic flora (algae, bryophytes, fungi and lichens) of the "Bosco Pomieri", an old-growth forest included in the Madonie Regional Park (N-Sicily). This area presents a significantly high biodiversity (41 algae, 41 bryophytes, 141 fungi, and 105 lichens) and also hosts several taxa of high biogeographic value.
\end{abstract}

Key words: : Biodiversity, Algae, Bryophytes, Fungi, Lichens, Old-growth forest, Sicily.

\section{Introduction}

Old-growth forests are natural forests that have developed over a long period, without experiencing severe, stand-replacing disturbances such as fire, windstorm, or logging (UNEP/CBD/SBSTTA 2001). According to the Italian Ministry for Environment and Protection of Land and Sea, these are ecosystems in which natural dynamics create a mosaic of all the forest regeneration phases, including the senescing one. Such phase is characterized by large old trees, deadwood, and a vascular plant species composition that is consistent with the biogeographical context and includes highly specialized taxa related to the small-scale disturbance and the microhabitats resulting from structural heterogeneity (Blasi \& al. 2010).

In Sicily, 472 hectares were recognized as old-growth forests mainly distributed in Regional Natural Parks, Natural Reserves, Sites of Community Importance (SCI) and Special Protected Areas (SPA). In particular, 18 forest areas, located over $1000 \mathrm{~m}$ of altitude and characterized by high index of woodiness, were surveyed in the provinces of Caltanissetta, Catania, Messina and Palermo (La Mela Veca \& al. 2015).

In the frame of a research project granted by the University of Palermo, an investigation was carried out in the "Bosco Pomieri", an old-growth forest included in the Madonie Park (N-Sicily). In particular, we have focused our attention on the different cryptogamic coenosis found within the "Bosco Pomieri". 
The "Bosco Pomieri" is crossed by streams of different size with variable streamflow during the different seasons. For this reason, we decided to also investigate freshwater benthic algae. Benthic algae (periphyton), organisms attached to different substrate types in aquatic environments, represent a primary source in many water bodies (Stevenson 1996; Wehr \& Sheath 2003; Mannino 2010). Microalgae are the most representative constituents of benthic assemblages, with a predominance of cyanobacteria, Chlorophyceae and diatoms (Lowe 1996; Stevenson 1996). Numerous studies have focused on benthic algae inhabiting water bodies (rivers, streams or springs) of mountainous regions (Dell'Uomo \& Ciccotti 1977; Dell'Uomo 1986, 2003; Potapova 1996; Daga \& al. 2014; Zębek \& Szymańska 2014; Barinova \& al. 2015). However, diatoms are the most studied component of periphyton, as consequence of their wide use as indicators of water body's quality, and have been widely studied in Alpine regions (Rott \& al. 2006; Cantonati \& Lange-Bertalot 2010; Falasco \& Bona 2011; Cantonati $\&$ al. 2012; Delgado \& al. 2013; Mogna \& al. 2015). Instead, benthic algae inhabiting forested environments have been scarcely studied so far (Mosisch \& Bunn 1997; Sabater \& al. 1998). In Sicily, freshwater benthic algae have been poorly studied (Mannino 2001, 2007; Mannino \& al. 2003; Finocchiaro \& al. 2009, 2011) compared to phytoplankton communities (Calvo \& al. 1993; Barone 2003; Naselli Flores \& Barone, 2007, 2012; Naselli Flores \& al. 2015). Data on benthic algae inhabiting Sicilian forested environments are totally lacking.

The bryophytes constitute a remarkable structural and functional component occurring in all layers of the old growth forests. Their functional role is very articulated contributing in various ways to the maintenance of ecosystem balance. They are capable of regularizing and optimizing the flow of water from precipitation. In particular, they reduce stem flow and water runoff speed on the ground, limiting surface erosion and favoring infiltration and, moreover, store large amounts of water, which then release slowly, mitigating drought and frost. Due to their trample-resistant structure and regenerative capacity, the bryophytes form mats that protect the soil; filter nutrients by capturing them from the atmosphere in liquid phase; provide food, shelter and nesting material for small animals and invertebrates; make the soil damp and suitable for the colonization of seedlings thus promoting the renewal of the forest (Cortini Pedrotti 1992; Bahuguna \& al. 2013).

Fungi are considered indicators of primeval in old-growth forests (Parmasto 2001) and they play an essential role in the decomposition and nutrient cycling of coarse woody debris (Cline \& Spurr 1942). The diversity and abundance of saprotrophic and mycorrhizal fungi is directly correlated to the diversity and abundance of coarse woody material. Saproxylic (dead-wood-associated) fungi are among the most threatened species in European old-growth forests (Lachat \& Bütler 2009). Polypore species richness is also an indicator of biodiversity in old-growth forest stands (Ylläsjärvi 2011).

Lichen species richness was known to be related to European old-growth forests and several species are mainly confined to these ecosystems (Rose 1976; Nilsson \& al. 1995; Hilmo \& Sastad 2001; Gustafsson \& al. 2004). In the last decade, surveys carried out in Mediterranean environments (old-growth and non-old-growth forests) have confirmed that old trees, high levels of basal area, a broad range of diameter classes, and high understory diversity are the main structural features affecting lichen richness also in these stands (Aragón \& al. 2010; Brunialti \& al. 2010; 2013). In addition, old-growth stands tend to harbor most species of conservation importance with respect to younger and structurally more homogeneous stands (Ravera \& al 2010; Brunialti \& al. 2010, 2015). 


\section{Material and methods}

\section{Study area}

The "Bosco Pomieri" is included in the Madonie Regional Park, Contrada Pomieri, municipality of Petralia Sottana, province of Palermo (sheet no. 610 - Castelbuono, Italian Military Geographic Institute). One of the most interesting aspects of this forest plant community is its considerable size and the geographical location corresponding to the southernmost limit of the distribution area of durmast oak in Europe (Merlino \& al. 2014).

The "Bosco Pomieri" is a mixed oak wood (Fig. 1), whose last forest uses date back to about 1950 (Bagnato \& al. 2012), characterized by the presence of a number of old trees of Quercus petraea subsp. austrothyrrenica Brullo, Guarino \& Siracusa and a dense shrub layer with Ilex aquifolium L. In the forest area we also found Fagus sylvatica L., Acer campestre L., A. monspessulanum L., A. obtusatum Willd., A. pseudoplatanus L., Ulmus glabra Huds., Sorbus torminalis L., Malus sylvestris (L.) Mill., and, sporadically on more open areas, Quercus cerris L. and Q. congesta C. Presl. Shrubby species, such as Daphne laureola L., Prunus spinosa L., Crataegus laciniata Ucria, Ruscus aculeatus L. and, Rhamnus catharticus L., are also present in the investigated area (Brullo 1984; Raimondo 1998). The herbaceous layer is characterized by Aquilegia vulgaris L. and other species of phytogeographical relevance such as Anemone apennina L., Cyclamen repandum Sibth. \& Sm., C. hederifolium Aiton, Dactylorhiza romana (Sebast.) Soó, Drymochloa drymeia (Mertens \& W. D. J. Koch) Holub, Hieracium racemosum subsp. pignattianum (Raimondo \& Di Grist.) Greuter, Pteridium aquilinum (L.) Kuhn, Symphytum gussonei F. W. Schultz, and Viola rechenbachiana Boreau (Raimondo 1998). The forest falls in the plant association Ilici-Quercetum austrotyrrhenicae (Ilici-Quercetum petraeae Brullo \& Marcenò in Brullo 1984), described by Brullo (1984). Referring to IPLA (2008) assessment the "Bosco Pomieri" belongs to the category "Oak woods with durmast and pubescent oak" (QU10X) and the category "Mesophilous beech wood on silicate substrata" (FA10B).

In Bosco Pomieri, the mean annual temperature $(\mathrm{T})$ is $13.6^{\circ} \mathrm{C}$, the mean max $\mathrm{T}$ is $17.5^{\circ} \mathrm{C}$ while the mean min $\mathrm{T}$ is $9.6^{\circ} \mathrm{C}$. The mean annual rainfall is $836 \mathrm{~mm}$ and is mainly distributed from October to April. Fog is persistent along the year and contributes to the mitigation of temperature in summer and provides additional hidden precipitations during the dry period.

\section{Sampling and analysis}

The investigation on cryptogamic flora was carried out in 2018-2020 and various habitat types have been considered, in accordance with the different cryptogamic components.

Periphytic algae were collected by scraping off at least five stones or cobbles $(5-15 \mathrm{~cm})$ randomly chosen and covered by brownish or blue-green coatings and tufts of green and red algae. The epiphytic algae were collected by squeezing bryophytes and macroalgae. The samples were preserved in a $4 \%$ formalin solution. To analyse diatoms, samples were digested in $30 \% \mathrm{H}_{2} \mathrm{O}_{2}$ overnight to remove organic matter by oxidation. Cleaned valves were mounted in Naphrax. Taxa were identified according to Starmach (1985), Krammer \& Lange-Bertalot (1986, 1988, 1991a, 1991b), John \& al. (2002), Wehr \& Sheath (2003), Komárek \& Anagnostidis (2005) and specific contributions. The modern species names come from AlgaeBase (Guiry \& Guiry 2020). Some ecological indicator values (pH, salinity, trophic state and, moisture) were recorded for diatom taxa according to Van Dam \& al. (1994). 


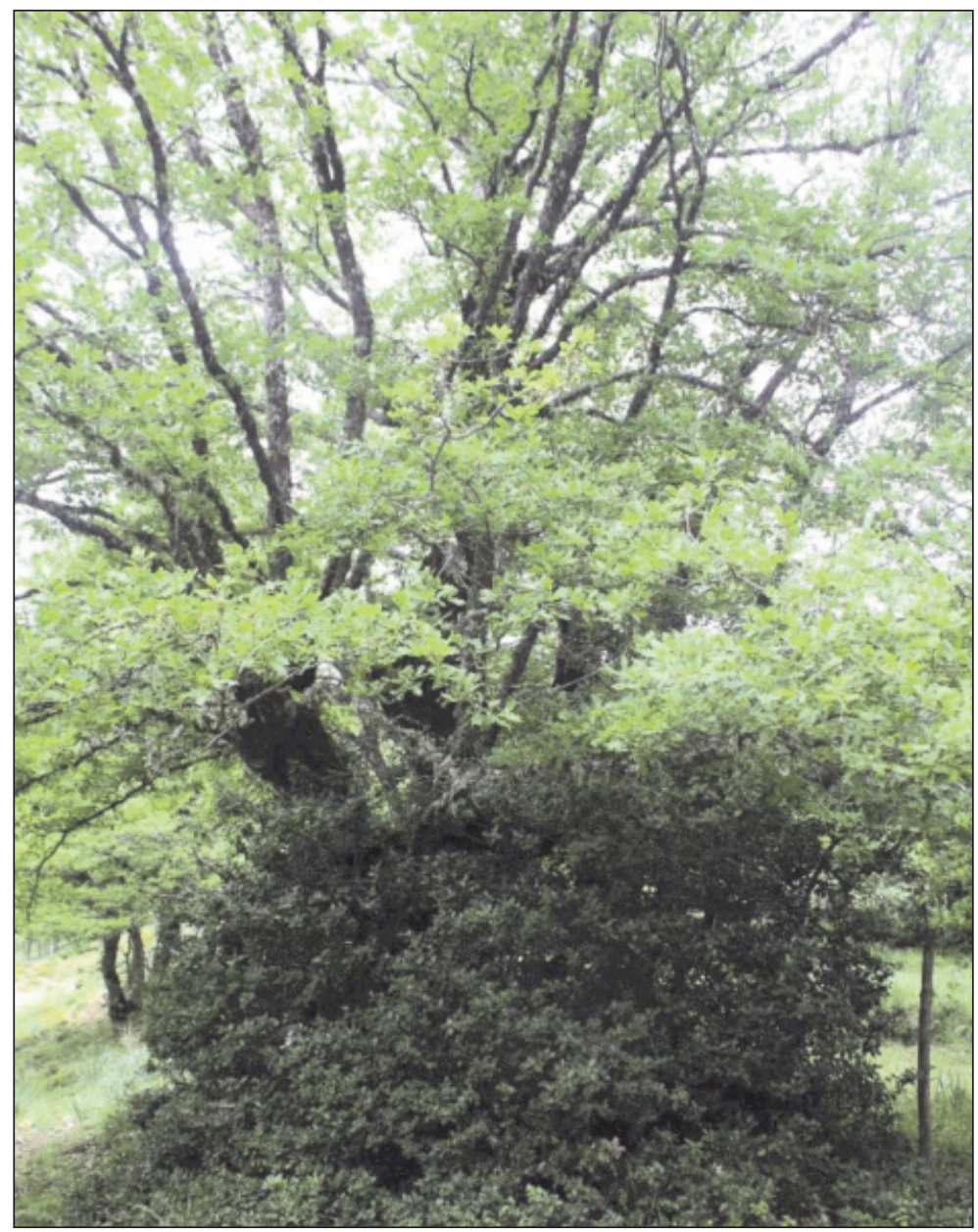

Fig. 1. Quercus petraea subsp. austrothyrrenica and Ilex aquifolium, characterizing elements of the forest of Pomieri.

Bryophyte data have been taken from the literature and in part are unedited, being the result of the determination of some specimens kept at the Herbarium Mediterraneum Panormitanum (PAL). The material was collected in several microhabitat within the forest, including some humid environments. The nomenclature followed is that in Söderström \& al. (2016) for liverworts, that in Ros \& al. (2013) and Aleffi \& al. (2008) for the mosses. Type of growth is drawn from Hill \& al. (2007) while the ecological category is that of each taxon in the study area. Bioindication indices refer to Hill \& al. (2007) for the content of nitrogenous salts in substrate (N) and to Düll (1991), for light (L), reaction of substrate $(\mathrm{R})$, temperature $(\mathrm{T})$ and moisture $(\mathrm{M})$ factors because they better agree with our experience in Sicily. The mean values of the indices of these five major ecological factors were calculated to draw a radar diagram. 
Life strategies (sensu During 1979, 1992) are those reported by Dierßen (2001). They have been grouped into 4 main categories as follows: $\mathrm{C}=$ colonists and pioneer colonists; $\mathrm{S}=$ short-lived shuttle; $\mathrm{P}=$ perennials, perennials competitive and stress tolerant perennials; $\mathrm{L}=$ long lived shuttle; $\mathrm{D}=$ dominant. Human impact data were drawn from Dierßen (2001).

According to the methodology reported in Venturella \& al. (2015), the macro-morphological characters of collected fungi were evaluated with a Leica MS5 binocular microscope while the microscopic features were evaluated with a Leica DLMB microscope using tap water. The nomenclature of fungi refers to The Index Fungorum Database. Ecological categories for fungi refer to Venturella \& Gargano (2008).

Lichens list derives both from bibliographic data (Schicchi \& al. 1997, Calatayud \& Rambold 1998, Tretiach \& Hafellner 1998) and from recent field collections. The latter have been identified in the field, using a magnifying glass. For more complex identifications, samples were transferred to the laboratory and identified using a stereo microscope for macroscopic structures (such as reproductive and vegetative structures) and chemical spot tests $\mathrm{K}$ (a solution of 10\% potassium hydroxide), C (sodium hypochlorite solution), $\mathrm{KC}$. A light microscope was used for identification of microscopic characters, such as paraphyses, asci and spores. For the identification of the lichen species several keys were used, mainly Clauzade \& Roux (1985) and Smith \& al. (2009). Nomenclature refers to The Index Fungorum Database. Bio-ecological characterization follows Nimis (2016).

The list of algae, bryophytes, fungi and, lichens recorded in "Bosco Pomieri" is reported in Electronic Supplementary File 1.

\section{Results and Discussion}

\section{Algae}

In all, 41 taxa belonging to Cyanophyta, Rhodophyta, Chlorophyta and Heterokontophyta (Bacillariophyceae) were found, 32 of which identified to a specific level. Taxa belonging to diatoms were found to be the most important component of the algal community, followed by algae belonging to Chlorophyta. The genera with the highest number of taxa belong to diatoms: Navicula Bory (4 taxa, Fig. 2) and Gomphonema Ehrenberg (3 taxa). The most abundant species also belong to diatoms: Cocconeis placentula Ehrenberg (Fig. 3), Cymbella tumida (Brébisson) Van Heurck, Fragilaria crotonensis Kitton, Navicula tripunctata (O.F. Müller) Bory and Nitzschia palea (Kützing) W. Smith. Species belonging to the genera Cocconeis Ehrenberg, Gomphonema and Rhoicosphenia Grunow had the highest specificity for macroalgae. The dominance of pennate diatoms and the absence of Centrales might be due to shallow waters of this habitat characterized by continuously flowing waters. Diatoms, due to their sensitivity to the variations in the chemical and physical properties of the environment (e.g. $\mathrm{pH}$, salinity, trophic state, etc.), gave us useful information on this habitat. In particular, collected taxa were mainly alkaliphilous, fresh brackish $(<0.9 \%$ ), eutraphentic (taxa with preferences for nutrient-enriched, eutrophic waters) and linked to water bodies, and wet places.

Among macroalgae, the Chlorophyta Oedogonium Link ex Hirn and Spirogyra Link were the most abundant taxa. Only sterile filaments were observed in Mougeotia C. Agardh, Oedogonium and Spirogyra. Gametophytes (with carposporophytes) of Lemanea fluviatilis (L.) C. Agardh, occurring in clumps of 10-20 individuals and subtended by cushion of 


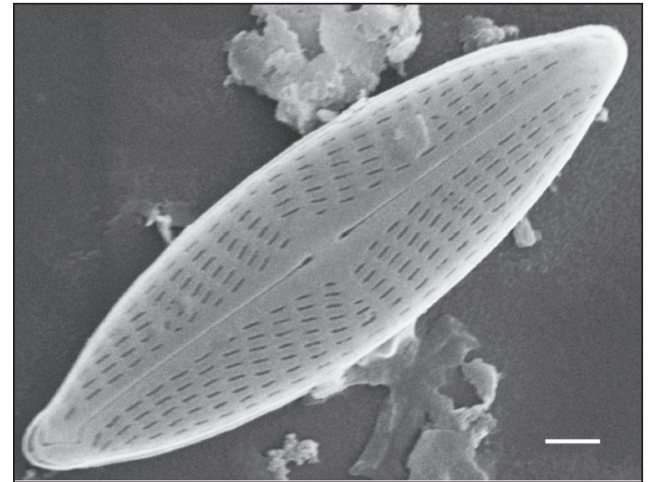

Fig. 2. Navicula cryptotenella Lange-Bertalot: SEM external view of the entire valve face. Scale bar $=1 \mu \mathrm{m}$.

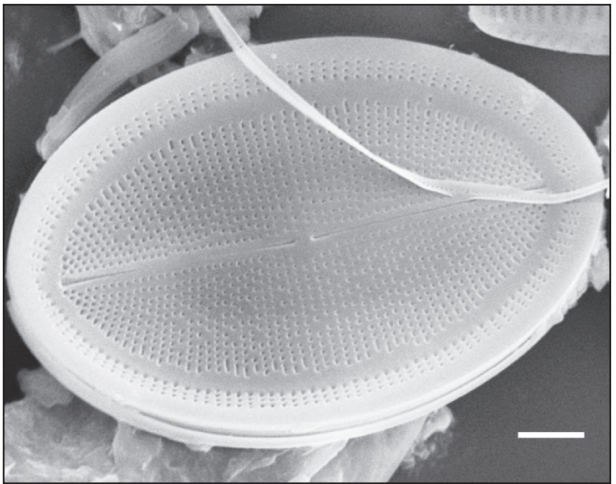

Fig. 3. Cocconeis placentula Ehrenberg: SEM external view of the entire valve face. Scale bar $=$ $3 \mu \mathrm{m}$.

sparingly branched filaments (chantransia phase), were also found. Lemanea fluviatilis, already recorded in Sicilian water bodies (Barone \& al. 1995; Mannino 2001), mainly inhabits water bodies characterized by swift currents but it is also present in continuously flowing waters.

This species is widely distributed in unpolluted or moderately polluted water bodies. Even though results from the present study are not conclusive, they provide accounts and new data on this environment.

\section{Bryophytes}

Regarding the bryophytic component, to date 41 taxa are known in the Pomieri forest, 30 of which are mosses and 11 are liverworts. Among them, the species Pedinophyllum interruptum was identified. This taxon is particularly interesting since it was previously known in Sicily only from an old report in one locality in the Nebrodi Mountains (Aleffi $\&$ al. 2008). The high number of liverworts in the area agrees with what has been observed by Puglisi \& al. (2015) for the flora of the Madonie Mountains, which is characterized by the abundance of this component if compared to that of the other Sicilian mountain systems. Likewise, the genus Orthotrichum Hedw., the most represented moss in the forest, as well as the Orthotrichaceae family, presents a high specific richness in the Madonie mountains and, more generally, in the epiphytic flora of the Sicilian mountain systems (Raimondo \& Dia 1981; Campisi \& al. 2009).

In Pomieri forest 5 epiphytic species are present, 3 of which (Orthotrichum lyelii, $O$. speciosum and O. striatum) are sensitive to atmospheric pollution (Dierßen 2001).

Most of taxa (32\%) are terricolous such as moss Bartramia pomiformis (Fig. 4) while, with regards to type of growth, the Turf species (Tf) prevails (44\%). As shown in the radar graph of Fig. 5, from the ecological point of view, the bryophyte contingent so far found in the forest has a mesophilic, averagely acidophilic, photophilic, microtherm character and it prefers poor nitrogen substrates. With regard to tolerance to the anthropogenic impact, most of the taxa (53\%) have a behavior ranging from ahemerobous to mesohemerobous, as Homalothecium sericeum (Fig. 6). 


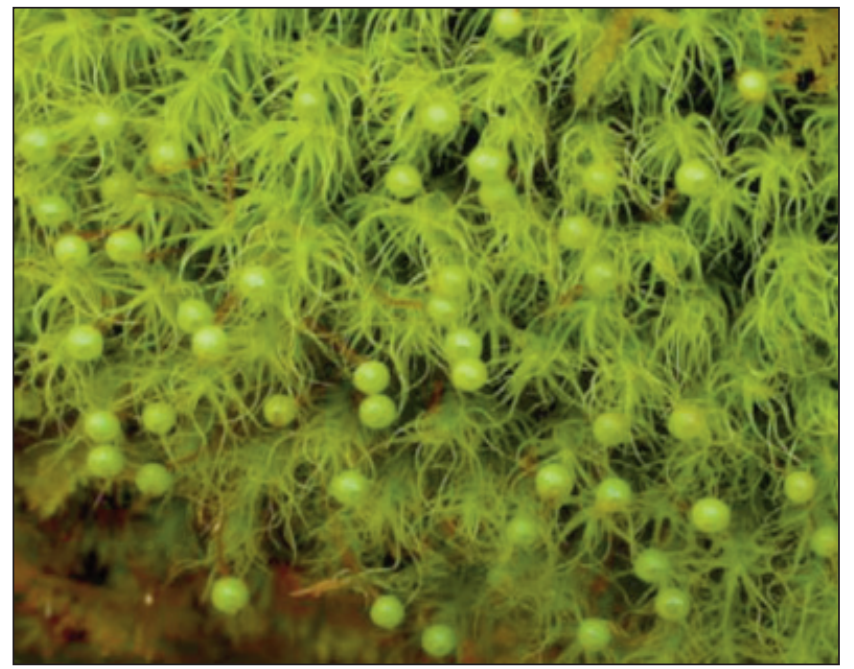

Fig. 4. Bartramia pomiformis Hedw.

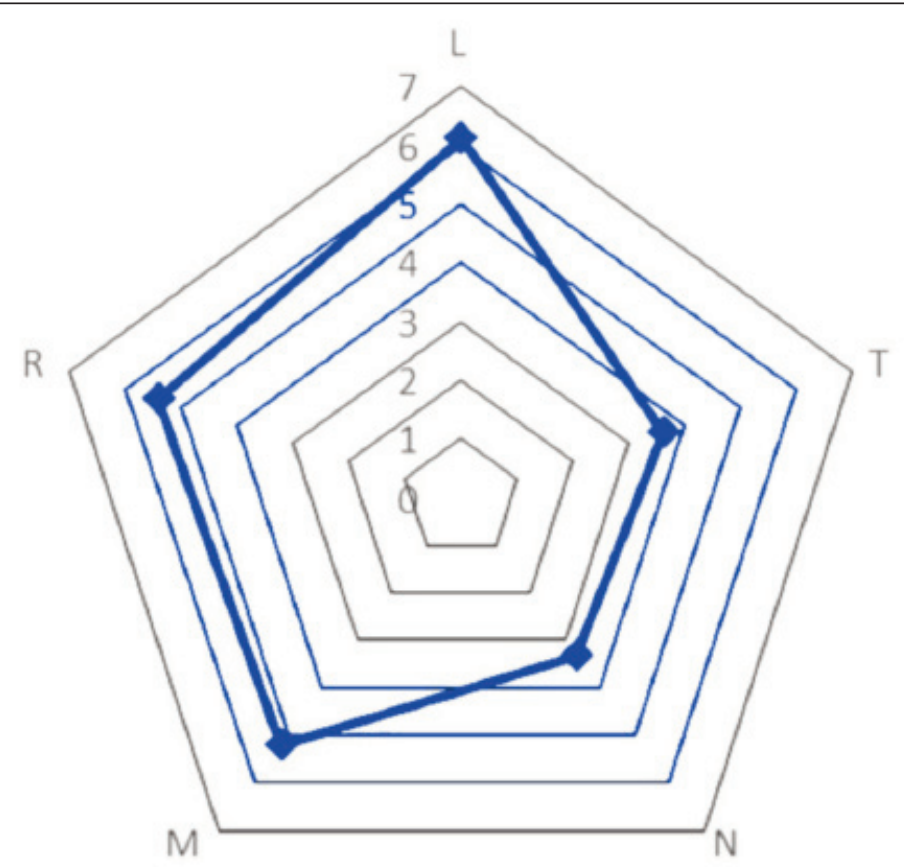

Fig. 5. Radar chart of mean bioindication indices of the recorded bryophyte florula: $\mathrm{L}-$ light; $\mathrm{T}-$ temperature; $\mathrm{N}$ - nitrogenous salts in substrate; $\mathrm{M}$ - moisture; $\mathrm{R}$ - reaction of substrate. Only the numeric values have been considered ( $\mathrm{X}$ values have been omitted). 


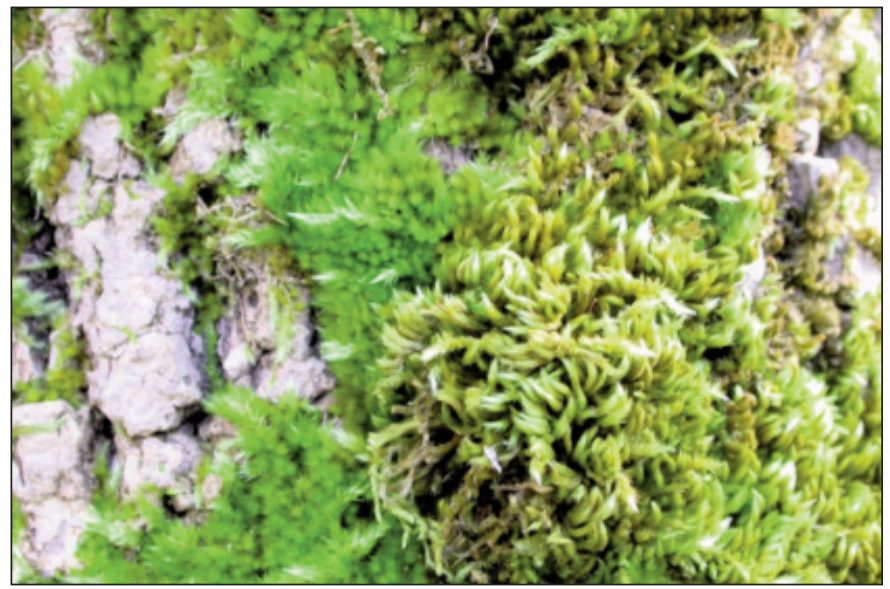

Fig. 6. Homalothecium sericeum (Hedw.) Bruch, Schimp. \& W. Gümbel.

An analysis of the percentage distribution of life strategies highlights the absence of annual species and ephemeral colonization species. Overall, the colonizing species and those characterized by short life are well represented (around 48\%) but, as shown in the histogram of Fig. 7, long living species $(\mathrm{P}+\mathrm{L}+\mathrm{D})$ affect more $(52 \%)$.

In agreement with the observations made by Dia \& Campisi (2015), comparing the percentage distributions of the life strategies in natural oak and artificial pine forests, these data indicate a fairly stable condition of the forest where long living or dominant bryophytes may maintain in the different microhabitats.

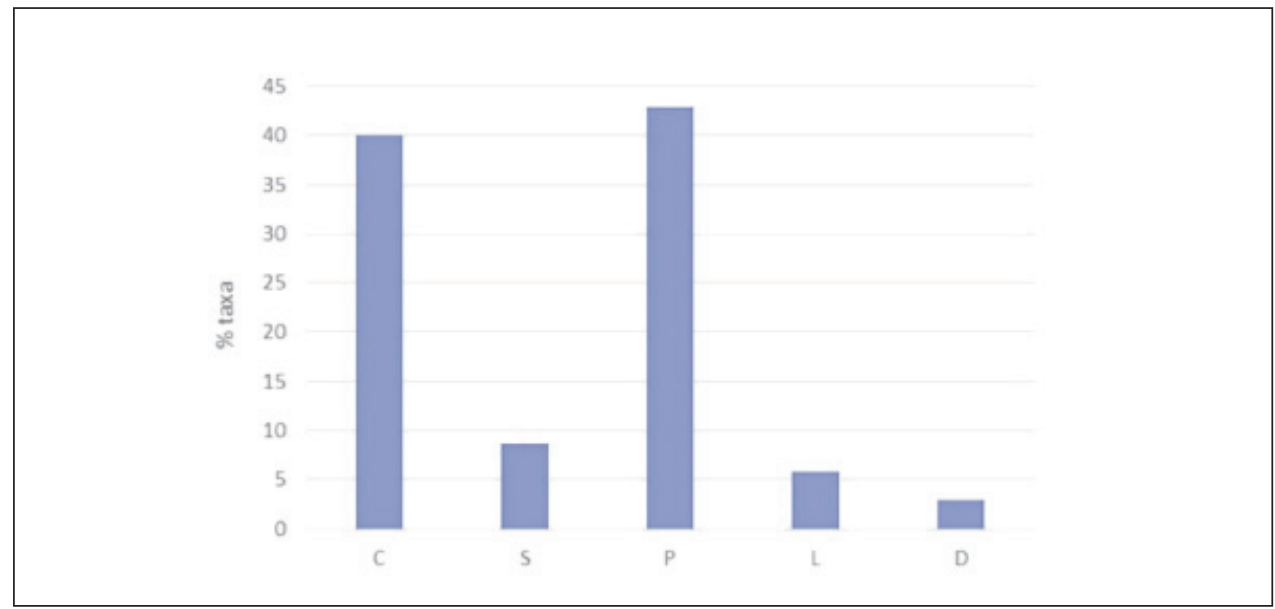

Fig. 7. Percentage incidence of life strategies of the recorded bryophyte florula: $\mathrm{C}=$ colonists and pioneer colonists; $\mathrm{S}=$ short-lived shuttle; $\mathrm{P}=$ perennials, perennials competitive and stress tolerant perennials; $\mathrm{L}=$ long lived shuttle; $\mathrm{D}=$ dominant. 


\section{Fungi}

In the forest of Pomieri the mortality of trees is on average of $8.1 \%$ and it is mainly caused by competition among the different plants, meteorological damages (wind, snow) and by the presence of pathogenic fungi, i.e. Fomes fomentarius (L.) J.J. Kickx (Bagnato \& al. 2012).

The high amount of deadwood in the forest of Pomieri mainly depends on stand age and human and animal disturbance. The deadwood is a typical feature of old-growth forests and plays a key role in maintaining biological diversity for different taxonomic groups such as plants, fungi and bryophytes.

The impacts caused by the presence of ungulates have a role on the composition and functions of the forest and the mycorrhizae, soil erosion and damage to the natural regeneration and the presence of synanthropic species (Kuijper \& al. 2014). Fungi are represented by 141 taxa included in 78 genera and 48 families. 112 taxa are terricolous, 28 lignicolous, and 1 fimicolous.

The most represented genera are Boletus L. (13 taxa, $9.2 \%)$, Russula Pers., Lactarius Pers., Cortinarius (Pers.) Gray (7 taxa, $4.9 \%$ ) and Amanita Pers. (6 taxa, $4.2 \%$ ).

As regards ecological categories (sensu Arnolds 1991) the results of investigation carried out in "Bosco Pomieri" showed that 31 taxa are saprotroph (S) (21,9\% of total recorded taxa). 23 taxa grow as saprotrophs on litter (16,3\% of total recorded taxa), 13 taxa (9.2 $\%$ of total recorded taxa) belong to terrestrial saprotrophs (St), and 6 taxa are saprotrophs on humus (4,2\% of total recorded taxa). 64 taxa (45.3\%) are mycorrhizal fungi (M) and $4(2.8 \%)$ necrotrophic parasites (Fig. 8).

Data analysis confirm the interpretation of Molina (2008) on the need to develop for old-growth forests long-term partnerships among professional mycologists, resource man-

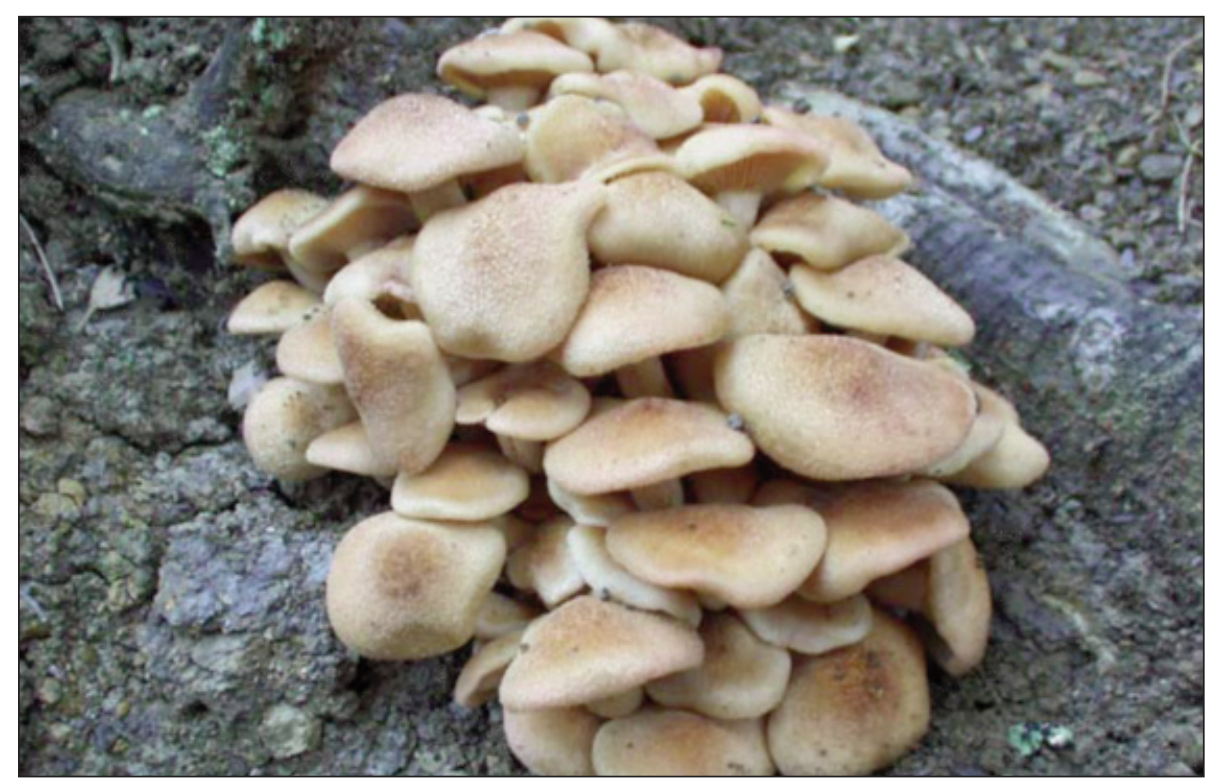

Fig. 8. Desarmillaria tabescens (Scop.) R.A. Koch \& Aime, a common necrotrophic parasite. 


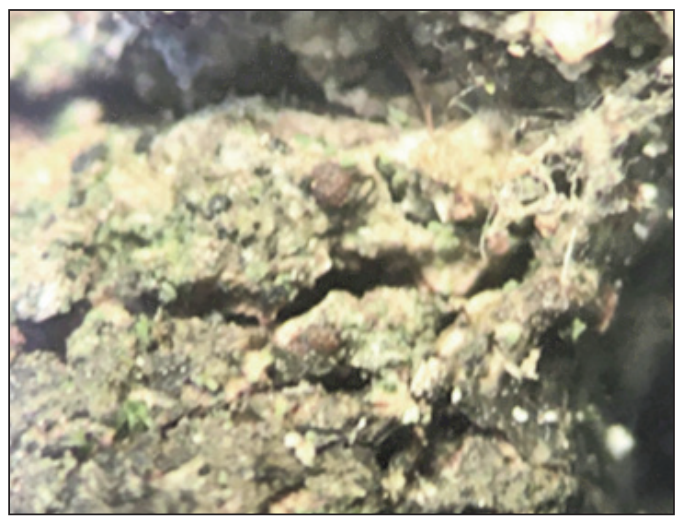

Fig. 9. Strangospora pinicola (A. Massal.) Körb.

agers and other scientists, and to apply mycological expertise to complex species and habitat conservation issues in an interdisciplinary setting.

\section{Lichens}

105 lichens are known to date in "Bosco Pomieri", 3 of them resulting from a recent survey - Gallowayella fulva, Phaeophyscia poeltii and Strangospora pinicola (Fig. 9) - are new to Sicily. These mainly epiphytic lichens, belong to 61 genera of 29 families. The most represented genera are Physcia (Schreb.) Michx. (8 taxa, 7.6\%), and Lecanora Ach. (7 taxa, 6.7\%).

Although these are mostly common species in the Mediterranean mountains, there are also species of conservation interest: Bellemerea cupreoatra, Rhizocarpon captans and the mentioned G. fulva, Ph. poeltii and S. pinicola, only known from here in Sicily; Sclerophora pallida, included in the Italian red list of epiphytic lichens as "Vulnerable" together with S. pinicola - and Pectenia plumbea included as "Near Threatened" (Nascimbene \& al. 2013).

As regards a bio-ecological characterization, 52 taxa (49\%) are crustose, 43 taxa (41\%) belong to the category foliose, 7 (7\%) fruticose, and 4 squamulose $(4 \%)$, in line with the lichen habitat "beech forests with mesophytic affinity" in central Italy (Ravera \& al. 2006). As usual at these latitudes, the more common photobiont is represented by green algae other than Trentepohlia (88 taxa, 85\%), followed by cyanobacteria (12 taxa, 11\%) and

Table 1. Ecological indicator values of the recorded lichen florula (see Nimis 2016).

\begin{tabular}{|c|c|c|c|c|c|c|c|c|c|c|c|c|c|}
\hline Class & 0 & 1 & $1-2$ & 2 & $1-3$ & $2-3$ & $2-4$ & 3 & $3-4$ & $3-5$ & 4 & $4-5$ & $2-5$ \\
\hline pH of the substratum & 0 & 0 & 14 & 2 & 8 & 47 & 10 & 7 & 4 & 4 & 0 & 6 & 3 \\
\hline Light (solar irradiation) & 0 & 0 & 0 & 0 & 1 & 4 & 1 & 9 & 23 & 23 & 8 & 36 & 0 \\
\hline Xerophytism (aridity) & 0 & 0 & 10 & 8 & 1 & 22 & 2 & 19 & 29 & 1 & 8 & 4 & 1 \\
\hline Eutrophication & 0 & 10 & 24 & 1 & 15 & 29 & 4 & 2 & 12 & 2 & 0 & 4 & 2 \\
\hline Poleotolerance & 3 & 24 & 49 & 0 & 27 & 2 & & & & & & & \\
\hline
\end{tabular}


Trentepohlia (2 taxa, 3\%). The prevailing reproductive strategy is sexual (72 taxa, 69\%), while propagation is more assured by soredia (21 taxa, 20\%) rather than isidia (12 taxa, 11\%).

Epiphytic lichens (55\%) prevail over epilithic (23\%) taxa. Other substrates (wood, mosses/plant debris) are less colonized. In "Bosco Pomieri" prevail lichen taxa more commonly found on acidic to slightly basic substrata, in sites with much diffused light to sunexposed, resistant up to a weak eutrophication and really heterogeneous with respect to environmental humidity (Table 1).

Regarding to the human impact, the best represented species are those with a mean tolerance, usually occurring also in moderately disturbed areas (49 taxa, 47\%). Nevertheless, species sensitive to human impact are well represented: species mostly occurring in natural or semi-natural habitats (24 taxa, 23\%) and species exclusively occuring on old trees in ancient, undisturbed forests (3 taxa, 3\%), which reveal a low impact. The most colonized trees are F. sylvatica and Q. petraea subsp. austrothyrrenica.

\section{Conclusion}

This study represents one of the few examples in the literature of a multidisciplinary approach in the study of the flora living in old-growth forests. Moreover, this paper represents the first comprehensive contribution to the cryptogamic flora of the "Bosco Pomieri".

The analysis of the algal flora, mainly composed by alkaliphilous, fresh brackish (< $0.9 \%$ ), of continuously flowing waters and eutraphentic (taxa with preferences for nutrient-enriched, eutrophic waters) taxa, allowed to clearly depict the ecological characteristics of the streams crossing the "Bosco Pomieri".

Based on the analysis of the bryophytic flora it is possible to make some considerations. In particular, the prevalence of aemerobous or mesoemerobous species, as well as the high incidence of pluriennial species, suggests that in the Bosco Pomieri the microhabitats in which bryophytes live are on the whole in a good conservation status. Similarly, the scarce presence of nitrophilous species leads us to think that bryophytes suffer little from disturbing factors such as grazing, which instead, from a study conducted by Bagnato \& al. (2012) appears to exert a high impact on the vascular component.

Furthermore, the presence of the rare taxon in Sicily Pedinophyllum interruptum highlights even more the interest of the site and the importance of maintaining or implementing adequate protection measures.

In this regard, the survey highlights the opportunity in the future to evaluate and monitor the population size of this taxon, also considering that for the locality previously known of the Nebrodi Mountains, there are no precise indications and therefore it is not easy to locate the population. The high percentage of ectomycorrhizal fungi detected $(67.7 \%)$ is a good index of forest health considering that $20 \%$ is the critical threshold under which a forest ecosystem is considered to be in decline (Arnold 1991).

Although most of the reported lichens are common and typical of the Mediterranean mountain habitats, elements of conservation interest and unique finds for Sicily are housed in this forest. Furthermore, the bio-ecological characterization of the lichen flora confirms the conservation interest of the site underlined through the analysis of the bryophytic flora, giving "Bosco Pomieri" a role of relevance and responsibility in safeguarding island biodiversity. 
The importance of the collected data is also highlighted by the presence of taxa of high biogeographical value, which provide useful indications for the management and conservation of this important forest ecosystem.

\section{Acknowledgements}

Financial support by University of Palermo (2012-ATE-0496, FFR projects) is gratefully acknowledged. All authors contributed equally to this work.

\section{References}

Aleffi, M., Tacchi, R. \& Cortini Pedrotti, C. 2008: Check-list of the Hornworts, Liverworts and Mosses of Italy. - Bocconea 22: 5-254.

Aragón, G., Martínez, I., Izquierdo, P., Belinchón, R. \& Escudero, A. 2010: Effects of forest management on epiphytic lichen diversity in Mediterranean forests. - Appl. Veg. Sci. 13: 183-94. https//doi.org/10.1111/j.1654-109X.2009.01060.x

Arnolds, E. 1991: Decline of ectomycorrhizal fungi in Europe. - Agric. Ecosyst. Environ. 35: 209244. https//doi.org/10.1016/0167-8809(91)90052-Y

Bagnato, S., Merlino, A., Mercurio, R., Solano, F., Scarfò, F. \& Spampinato, G. 2012: Le basi conoscitive per il restauro forestale: il caso di Bosco Pomieri (Parco Regionale delle Madonie, Sicilia).-Forest@,9: 8-19. https//doi.org/10.3832/efor0679-008

Bahuguna, M. Y., Gairola, S., Semwal, D. P., Uniyal, P. L. \& Bhatt, A. B. 2013: Bryophytes and Ecosystem. - Pp. 279-296 in: Gupta, R. K. \& Kumar, M. (eds), Biodiversity of Lower Plants. New Delhi.

Barinova, S., Boboev, M. \& Hisoriev, H: 2015: Freshwater algal diversity of the South-Tajik Depression in a high-mountainous extreme environment, Tajikistan. - Turk. J. Bot. 39: 535546. https//doi.org/10.3906/bot-1406-45

Barone, R. 2003. A critical inventory of freshwater phytoplankton in Sicilian lakes. - Bocconea 16(1): 355-365.

Barone, R., Naselli Flores, L. \& Colombo. P. 1995: Ecological and morphological observations on Lemanea fluviatilis (L.) C. A. Agardh, recorded for the first time in Sicily. - Giorn. Bot. Ital. 129(2): 7.

Blasi, C., Burrascano, S., Maturani, A. \& Sabatini, F. M. 2010: Foreste Vetuste in Italia. - Roma.

Brullo, S. 1984: Contributo alla conoscenza della vegetazione delle Madonie (Sicilia settentrionale). - Boll. Acc. Gioenia Sci. Nat. Catania 16(232): 351-420.

Brunialti, G., Frati, L. \& Ravera, S. 2015: Structural variables drive the distribution of the sensitive lichen Lobaria pulmonaria in Mediterranean old-growth forests. - Ecol. Indic. 53: 37-42. https//doi.org/10.1016/j.ecolind.2015.01.023

Brunialti, G., Ravera, S. \& Frati, L. 2013: Mediterranean old-growth forests: The role of forest type in the conservation of epiphytic lichens. - Nova Hedwigia 96(3-4): 367-381. https//doi.org/10.1127/0029-5035/2012/0069

Brunialti, G., Frati, L., Aleffi, M., Marignani, M., Rosati, L., Burrascano, S. \& Ravera, S. 2010: Lichens and bryophytes as indicators of old-growth features in Mediterranean forests. - Pl. Biosyst. 144(1): 221-233. https//doi.org/10.1080/11263500903560959

Calatayud, V. \& Rambold, J. 1998: Two new species of the lichen genus Immersaria (Porpidiaceae). - Lichenologist 30: 231-244.

Calvo, S., Barone, R., Naselli-Flores, L., Dongarrà, G., Lugaro, A. \& Genchi, G. 1993: Limnological studies on lakes and reservoirs of Sicily. - Naturalista Sicil., s. 4, 17: 1-292. 
Campisi, P., Dia, M. G. \& Provenzano, F. 2009: Analysis of the epiphytic bryophyte diversity of Sicily. - Pl. Biosyst. 143(1): 104-112. https//doi.org/10.1080/11263500903220216

Cantonati, M. \& Lange-Bertalot, H. 2010: Diatom biodiversity of springs in the Berchtesgaden National Park (northern Alps, Germany), with the ecological and morphological characterization of two species new to science. - Diatom Res. 25: 251-280. https//doi.org/ 10.1080/0269249X.2010.9705849

Cantonati, M., Angeli, N., Bertuzzi, E., Spitale, D. \& Lange-Bertalot, H. 2012: Diatoms in springs of the Alps: spring types, environmental determinants, and substratum. - Freshwater Sci. 31: 499-524. https//doi.org/10.1899/11-065.1

Clauzade, G. \& Roux, C. 1985: Likenoj de Okcidenta Europa. Ilustrita determinlibro. - Bull. Soc. Bot. Centre-Ouest 7: 1-893.

Cline, A. C. \& Spurr, S. H. 1942: The virgin upland forest of central New England: a study of old growth stands in the Pisgah Mountain section of southwestern, New Hampshire. - Harvard.

Cortini Pedrotti, C. 1992: Le Briofite quale componente strutturale e funzionale degli ecosistemi forestali. - Ann. Accad. Ita. Sci. For. 41: 146-161.

Daga, C., Soteras, F., Daniele, G. M. \& Dominguez, L. S. 2014: New records of freshwater algae and cyanobacteria from mountain streams of Córdoba (Argentina). - Bol. Soc. Argent. Bot. 49(4): 447-456.

Delgado, C., Ector, L., Novais, M. H., Blanco, S., Hoffmann, L. \& Pardo I. 2013: Epilithic diatoms of springs and spring-fed streams in Majorca Island (Spain) with the description of a new diatom species Cymbopleura margalefii sp. nov. - Fottea 13(2): 87-104. https//doi.org/10.5507/fot.2013.009

Dell'Uomo, A. 1986: La flora algale del Fiume Aso (Marche - Italia). - Arch. Bot. Biogeogr. Ital. 62(1-2): 69-82.

Dell'Uomo, A. 2003: Algae of running waters in Italy and their importance for monitoring rivers. Bocconea 16(1): 367-377.

Dell'Uomo, A. \& Ciccotti, A. 1977: Le alghe e le associazioni algali reofile del Torrente Ussita (Italia Centrale). - Riv. Idrobiol. 16(1-2): 55-73.

Dia, M. G. \& Campisi P. 2015: Life forms, life strategies and ecological indices of bryophytes for bioindication in wood areas: a case of study in the "Bosco della Ficuzza, Rocca Busambra, Bosco del Cappelliere e Gorgo del Drago" Oriented Nature Reserve (West Sicily). - Fl. Medit. 25(Special issue): 167-178. https//doi.org/10.7320/FlMedit25SI.167

Dierßen, K. 2001: Distribution, ecological amplitude and phytosociological characterization of European bryophytes. - Berlin \& Stuttgard.

Düll, R. 1991: Valori degli indicatori ecologici per muschi ed epatiche. Pp. 69-91 in: Mastracci, M. (ed.), Congresso internazionale di Briologia. - L'Aquila.

During, H. J. 1979: Life strategies of bryophytes: A preliminary review. - Lindbergia 5: 2-18.

During, H. J. 1992: Ecological classifications of bryophytes and lichens. Pp. 1-31 in: Bates, J. W. \& Farmer, A. M. (eds), Bryophytes and Lichens in a Changing Environment. - Oxford.

Falasco, E. \& Bona, F. 2011: Diatom community biodiversity in an Alpine protected area: a study in the Maritime Alps Natural Park. - J. Limnol 70: 157-167. https//doi.org/10.4081/jlimnol.2011.157

Finocchiaro, M., Torrisi, M. \& Ferlito A. 2009: Caratterizzazione delle comunità di diatomee bentoniche del bacino idrografico del fiume Simeto (Sicilia orientale) mediante applicazione dell'Indice Diatomico di Eutrofizzazione/Polluzione (EPI-D). - Biol. Ambient. 23(1): 53-66.

Finocchiaro, M., Torrisi, M., Ferlito, A., Dell'Uomo, A. \& Ector L. 2011: Biodiversità algale in Sicilia: diatomee rare o notevoli del bacino idrografico del fiume Simeto. - Biogeographia 30: 13-29. https//doi.org/10.21426/B630110548 
Guiry, M. D. \& Guiry, G. M. 2020: AlgaeBase. - https://www.algaebase.org [Last accessed 03.07.2020].

Gustafsson, L., Appelgren, L., Jonsson, F., Nordin, U., Persson, A. \& Weslien, J. O. 2004: High occurrence of red-listed bryophytes and lichens in mature managed forests in boreal Sweden. - Basic Appl. Ecol. 5: 123-129. https//doi.org/10.1078/1439-1791-00223

Hill, M. O., Preston, C. D., Bosanquet, S. D. S. \& Roy, D. B. 2007: BRYOATT - Attributes of British and Irish Mosses, Liverworts and Hornworts With Information on Native Status, Size, Life Form, Life History, Geography and Habitat. - Huntingdon.

Hilmo, O. \& Sastad, S. M. 2001: Colonization of old-forest lichens in a young and an old boreal Picea abies forest: An experimental approach. - Biol. Conserv. 102: 251-259. https//doi.org10.1016/S0006-3207(01)00100-8

IPLA, 2008: I tipi forestali della Regione Siciliana. - Torino.

John, D. M., Whitton, B. A. \& Brook, A. J. (eds) 2002: The Freshwater Algal Flora of the British Isles. - Cambridge.

Komárek, J. \& Anagnostidis, K. 2005: Cyanoprokaryota 2. Teil: Oscillatoriales. Pp 759 In: Büdel, B., Krienitz, L., Gärtner, G. \& Schagerl, M. (eds), Süsswasserflora von Mitteleuropa. Heidelberg.

Krammer, K. \& Lange-Bertalot, H. 1986: Bacillariophyceae 1 Teil: Naviculaceae. Pp 876 in: Ettl, H., Gerloff, J., Heynig, H. \& Mollenhauer, D. (eds), Süßwasserflora von Mitteleuropea. - Stuttgart.

Krammer, K. \& Lange-Bertalot, H. 1988: Bacillariophyceae 2 Teil: Bacillariaceae, Epithemiaceae, Surirellaceae. Pp 596 in: Ettl, H., Gerloff, J., Heynig, H. \& Mollenhauer, D. (eds), Süßwasserflora von Mitteleuropa. - Stuttgart.

Krammer, K. \& Lange-Bertalot, H. 1991a: Bacillariophyceae 3 Teil: Centrales, Fragilariaceae, Eunotiaceae. Pp 576 in: Ettl, H., Gerloff, J., Heynig, H. \& Mollenhauer D. (eds), Süßwasserflora von Mitteleuropa. - Stuttgart.

Krammer, K. \& Lange-Bertalot, H. 1991b: Bacillariophyceae 4 Teil: Achnanthaceae. Kritische Ergänzungen zu Navicula (Lineolatae) und Gomphonema. Pp 437 in: Ettl, H., Gerloff, J., Heynig, H. \& Mollenhauer, D. (ed.), Süßwasserflora von Mitteleuropa. - Stuttgart.

Kuijper, D. P. J., Verwijmeren, M., Churski, M., Zbyryt, A., Schmidt, K., Jędrzejewska, B. \& Smit, C. 2014: What cues do ungulates use to assess predation risk in dense temperate forests? PLoS One 9(1): e84607. https://doi.org/10.1371/journal.pone.0084607

Lachat, T. \& Bütler, R. 2009: Identifying conservation and restoration priorities for saproxylic and old-growth forest species: A case study in Switzerland. - J. Environ. Manag. 44: 105-118. https//doi.org/10.1007/s00267-009-9281-0

La Mela Veca, C., Badalamenti, E., Maetzke, F. G., Pasta, S. \& La Mantia, T. 2015: Risultati dell'indagine preliminare per l'individuazione dei boschi vetusti in Sicilia. In: Travaglini, D., Rossi, P. \& Bucci, G. (eds), Abstract-book, 10th SISEF National Congress "Sostenere il pianeta, boschi per la vita Ricerca e innovazione per la tutela e la valorizzazione delle risorse forestali". - Firenze.

Lowe, R.L. 1996: Periphyton patterns in lakes. Pp. 57-76 in: Stevenson, R. J., Bothwell, M. L. \& Lowe, R. L. (eds), Algal ecology: freshwater benthic ecosystems. - San Diego.

Mannino, A. M. 2001: New records from the Oreto river (N.W. Sicily). - Phycologia 40: 71-72.

Mannino, A. M. 2007: Diatoms from thermal-sulphur waters of "Fiume Caldo" (North-western Sicily). - Cryptogam., Algol. 28(4): 385-396.

Mannino, A. M. 2010. Temporal and spatial variation of the algal community in a southern Mediterranean shallow system. - Cryptogam., Algol. 31(2): 255-272.

Mannino, A. M., Barone, R. \& Raimondo, F. M. 2003: First record of Paralemanea catenata (Rhodophyta) from Italian Peninsula. - Bocconea 16(2): 1053-1058.

Merlino, A., Baliva, M., Di Filippo, A., Piovesan, G. \& Solano, F. 2014: Analisi strutturali e dendroecologiche su popolamenti di Quercus petraea subsp. austrothyrrenica Brullo, Guarino e 
Siracusa nel Parco Regionale delle Madonie (Sicilia). Pp. 183-189 in: Ciancio, O. (ed.), Proceedings of the Second International Congress of Silviculture. - Firenze. https//doi.org/10.4129/2cis/-am-ana

Mogna, M., Cantonati, M., Andreucci, F., Angeli, N., Berta, G. \& Miserere, L. 2015: Diatom communities and vegetation of springs in the southwestern Alps. - Acta Bot. Croat. 74(2): 265285. https//doi.org/10.1515/botcro-2015-0024

Molina, R. 2008: Protecting rare, little known, old-growth forest-associated fungi in the Pacific Northwest USA: A case study in fungal conservation. - Mycol. Res. 112(6): 613-638. https//doi.org/10.1016/j.mycres.2007.12.005

Mosisch, T. D. \& Bunn, S. E. 1997: Temporal patterns of rainforest stream epilithic algae in relation to flow-related disturbance. - Aquat. Bot. 58: 181-193. https//doi.org/10.1016/S03043770(97)00001-6

Nascimbene, J., Nimis, P.L. \& Ravera S. 2013: Evaluating the conservation status of epiphytic lichens of Italy: A red list. - Pl. Biosyst. 147(4): 898-904. https//doi.org/10.1080/11263504.2012.748101

Naselli-Flores, L., \& Barone, R. 2007: Pluriannual morphological variability of phytoplankton in a highly productive Mediterranean reservoir (Lake Arancio, Southwestern Sicily). - Hydrobiol. 578: $87-95$. https//doi.org/10.1007/s10750-006-2815-z

Naselli-Flores, L. \& Barone R. 2012: Phytoplankton dynamics in permanent and temporary Mediterranean waters: is the game hard to play because of hydrological disturbance? Hydrobiol. 698: 147-159. https//doi.org/10.1007/s10750-012-1059-3

Naselli-Flores, L., Termine, R. \& Barone, R. 2015: Phytoplankton colonization patterns. Is species richness depending on distance among freshwaters and on their connectivity? - Hydrobiol. 764(1): 103-113. https//doi.org/10.1007/s10750-015-2283-4

Nilsson, S. G., Arup, U., Baranowski, R., Ekman, S. 1995: Tree dependent lichens and beetles as indicators in conservation forests. - Conserv. Biol. 9(5): 1208-1215. https//doi.org/10.1046/j.1523-1739.1995.9051199.x-i1

Nimis, P.L. 2016: The Lichens of Italy. A Second Annotated Catalogue. - Trieste.

Parmasto, E. 2001: Fungi as indicators of primeval and old-growth forests deserving protection. Pp. 81-88 In: Moore, D., Nauta, M., Evans, S. \& Rotheroe, M. (ed.), Fungal Conservation: Issues and Solutions (British Mycological Society Symposia,). - Cambridge https//doi.org/10.1017/CBO9780511565168.006

Potapova, M. 1996: Epilithic algal communities in rivers of the Kolyma Mountains, NE Siberia, Russia. - Nova Hedwigia 63(3-4): 309-334.

Puglisi, M., Campisi, P., Aiello, P., Dia, M. G. \& Privitera, M. 2015: Analysis of the bryophyte diversity of mountain ranges in Sicily. - Nova Hedwigia 100(3-4): 391-405. https//doi.org/10.1127/nova_hedwigia/2015/0236

Raimondo F. M. 1998: Carta del paesaggio e della biodiversità vegetale della provincia di Palermo. - Quad. Bot. Amb. Appl. 9: 3-160.

Raimondo, F. M. \& Dia, M. G. 1981: Ricerche sulla brioflora delle Madonie. 1. - Webbia 35(1): 87131. https://doi.org/10.1080/00837792.1981.10670215

Ravera, S., Genovesi, V. \& Massari, G. 2006: Phytoclimatic characterization of lichen habitats in central Italy. - Nova Hedwigia 82: 143-165. https://doi.org/10.1127/0029-5035/2006/0082-0143

Ravera, S., Genovesi, V., Falasca, A., Marchetti, M. \& Chirici, G. 2010: Lichen diversity of old growth forests in Molise (Central-Southern Italy). - Ital. Forest. Mont. 65(5): 505-517.

Ros, R. M., Mazimpaka, V., Abou-Salama, U., Aleffi, M., Blockeel, T. L., Brugués, M., Cano, M. J., Cros, R. M., Dia, M.G., Dirkse, G. M., Draper, I., El-Saadawi, W., Erdağ, A., Ganeva, A., Gabriel, R., González-Mancebo, J., Granger, C., Herrnstadt, I., Hugonnot, V., Khalil, K., Kürschner, H-, Losada-Lima, A., Luís, L., Mifsud, S., Privitera, M., Puglisi, M., Sabovljević, 
M,, Sérgio, C., Shabbara, H. M., Sim-Sim, M., Sotiaux, A., Tacchi., R., Vanderpoorten, A. \& Werner, O. 2013: Mosses of the Mediterranean, an annotated checklist. - Cryptog., Bryol. 34: 99-283. https//doi.org/10.7872/cryb.v34.iss2.2013.99

Rose, F. 1976: Lichenological indicators of age and environmental continuity in woodlands. Pp. 279-307 in: Brown, D. H., Hawksworth, D. L. \& Bailey, R. H. (eds), Lichenology: Progress and problems. - London

Rott, E., Cantonati, M., Fureder, L. \& Pfister, P. 2006: Benthic algae in high altitude streams of the Alps - a neglected component of the aquatic biota. - Hydrobiol. 562: . https//doi.org/195-216. 10.1007/s10750-005-1811-Z

Sabater, S., Gregory, S. V., Sedell, J. R. 1998: Community dynamics and metabolism of benthic algae colonizing wood and rock substrata in a forest stream. - J. Phycol. 34: 561-567. https//doi.org/10.1046/j.1529-8817.1998.340561.x

Schicchi, R., Mangione, M., Dia, M. G. \& Raimondo, F. M. 1997: Un nuovo modello di gestione per il biotopo "Querceti di Pomieri, Piano Farina e Piano Costantino" (Parco delle Madonie, Sicilia). - Quad. Bot. Ambient. Appl. 8: 65-100.

Smith, C. W., Aptroot, A., Coppins, B.J., Fletcher, A., Gilbert, O. L., James, P. W., Wolseley, P. A. (eds) 2009: The Lichens of Great Britain and Ireland. - London.

Söderström, L., Hagborg, A., von Konrat, M., Bartholomew-Began, S., Bell, D., Briscoe, L., Brown, E., Cargill, D. C., Costa, D. P., Crandall-Stotler, B. J., Cooper, E. D., Dauphin, G., Engel, J. J., Feldberg, K., Glenny, D., Gradstein, S. R., He, X., Heinrichs, J., Hentschel, J., Ilkiu-Borges, A. L., Katagiri, T., Konstantinova, N.A., Larraín, J., Long, D. G., Nebel, M., Pócs, T., Puche, F, Reiner-Drehwald, E., Renner, M. A. M., Sass-Gyarmati, A., Schäfer-Verwimp, A., Moragues, J. G. S., Stotler, R. E., Sukkharak, P., Thiers, B. M., Uribe, J., Váňa, J., Villarreal, J. C., Wigginton, M., Zhang, L. \& Zhu, R. L. 2016: World checklist of hornworts and liverworts. - PhytoKeys 59: 1-821. https//doi.org/10.3897/phytokeys.59.6261

Starmach, K. 1985: Chrysophyceae und Haptophyceae. Pp 596 in: Ettl, H., Gerloff, J., Heynig, H., Mollenhauer, D. (eds), Süßwasserflora von Mitteleuropa. - Stuttgart.

Stevenson, R. J. 1996: An introduction to algal ecology in freshwater benthic habitats. Pp. 3-30 in: Stevenson, R. J., Bothwell, M. L, Lowe, R. L. (eds), Algal ecology: freshwater benthic ecosystems. - San Diego.

Tretiach, M. \& Hafellner, J., 1998: A New Species of Catillaria from Coastal Mediterranean Regions. Lichenol. 30: 221-229. https//doi.org/10.1017/S0024282992000173

UNEP/CBD/SBSTTA, 2001: Main Theme: Forest Biological Diversity. Report of the Ad Hoc Technical Expert Group on Forest Biological Diversity. Subsidiary Body for Scientific, Technical and Technological Advice, Seventh Meeting. - Montreal.

Van Dam, H., Mertens, A. \& Sinkeldam, J. 1994: A coded checklist and ecological indicator values of freshwater Diatoms from the Netherlands. - Aquat. Ecol. 28: 117-133. https://doi.org/10.1007/BF02334251

Venturella, G., Gargano, M. L. 2008: Ecological features of macromycetes in Eucalyptus reforestations in Sicily (southern Italy). - Sydowia 61(1): 117-133.

Venturella, G., Gargano, M. L., Compagno, R., La Rosa, A., Polemis, E., Zervakis, G. I. 2015: Diversity of macrofungi and exploitation of edible mushroom resources in the National Park “Appennino Lucano, Val D’Agri, Lagonegrese” (Italy). - Pl. Biosyst. 150(5): 1030-1037. https//doi.org/10.1080/11263504.2014.1000997

Wehr, J. D. \& Sheath R. G. 2003: Freshwater algae of North America: ecology and classification. - San Diego.

Ylläsjärvi, I., Berglund, H. \& Kuuluvainen, T. 2011: Relationships between wood-inhabiting fungal species richness and habitat variables in old-growth forest stands in the Pallas-Yllästunturi National Park, Northern Boreal Finland. - Silva Fenn. 45(5): 995-1013. https//doi.org/ 10.14214/sf.83 
Zębek, E. \& Szymańska, U. 2014: Gastropods and periphytic algae relationships in the vicinity of a small hydroelectric plant on the Pasłęka River in northeast Poland. - Arch. Polish Fish. 22: 69-80. https//doi.org/10.2478/aopf-2014-0007

Addresses of the authors:

Patrizia Campisi ${ }^{1}$, Anna Maria Mannino $^{1 *}$, Giuseppe Venturella ${ }^{2}$ \& Sonia Ravera ${ }^{1}$ ${ }^{1}$ Department of Biological, Chemical and Pharmaceutical Sciences and Technologies (STEBICEF), University of Palermo, Via Archirafi, 38 I-90123 Palermo (Italy) ${ }^{2}$ Department of Agricultural, Food and Forest Sciences, University of Palermo, Viale delle Scienze, Bldg. 5, I-90128 Palermo (Italy)

*corresponding author 
